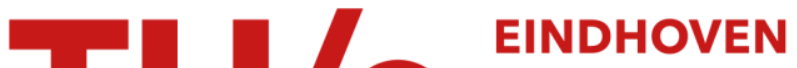 UNIVERSITY OF TECHNOLOGY
}

\section{Accuracy of assessment of wind speed in the built environment}

Citation for published version (APA):

Willemsen, E., \& Wisse, J. A. (2001). Accuracy of assessment of wind speed in the built environment. In J. A. Wisse, K. Kleinman, C. Geurts, \& M. de Wit (Eds.), Proceedings of the 3rd European \& African Conference on Wind Engineering (pp. 507-514). Technische Universiteit Eindhoven.

Document status and date:

Published: 01/01/2001

\section{Document Version:}

Publisher's PDF, also known as Version of Record (includes final page, issue and volume numbers)

\section{Please check the document version of this publication:}

- A submitted manuscript is the version of the article upon submission and before peer-review. There can be important differences between the submitted version and the official published version of record. People interested in the research are advised to contact the author for the final version of the publication, or visit the $\mathrm{DOI}$ to the publisher's website.

- The final author version and the galley proof are versions of the publication after peer review.

- The final published version features the final layout of the paper including the volume, issue and page numbers.

Link to publication

\section{General rights}

Copyright and moral rights for the publications made accessible in the public portal are retained by the authors and/or other copyright owners and it is a condition of accessing publications that users recognise and abide by the legal requirements associated with these rights.

- Users may download and print one copy of any publication from the public portal for the purpose of private study or research.

- You may not further distribute the material or use it for any profit-making activity or commercial gain

- You may freely distribute the URL identifying the publication in the public portal.

If the publication is distributed under the terms of Article $25 \mathrm{fa}$ of the Dutch Copyright Act, indicated by the "Taverne" license above, please follow below link for the End User Agreement:

www.tue.nl/taverne

Take down policy

If you believe that this document breaches copyright please contact us at:

openaccess@tue.nl

providing details and we will investigate your claim. 


\title{
Accuracy of assessment of wind speed in the built environment
}

\author{
E.Willemsen, ir. ${ }^{1}$
}

\author{
J.A. Wisse, prof.ir. ${ }^{2}$
}

\begin{abstract}
Wind climate in the built environment is assessed with wind tunnel simulations and criteria for wind discomfort and safety. Probability of occurrence of local winds with regard to speed, direction and time are derived from the wind tunnel results and data from an appropriate meteorological station. The present paper discusses error sources in the various steps. It is shown that at least a $20 \%$ standard deviation in the estimated local wind speeds has to be accounted for. This error has impact on the application of the various criteria.
\end{abstract}

\section{INTRODUCTION}

In the Netherlands a program has started for standardisation of the assessment of wind climate in building plans. Among the goals are standard criteria for wind discomfort and standard rules for wind tunnel investigations, CFD calculations and for use of climatological data. The program incorporates literature surveys and experience during three decades of wind comfort assessment with wind tunnel simulations. The standard for the assessment of wind discomfort and wind hindrance is meant as a document, available for incorporation in a building program and it is expected to become an important tool for authorities. It is necessary to determine the accuracy of the mentioned methods.

\section{METHODOLOGY}

In current practice in the Netherlands wind tunnel investigations yield the ratio $\mathrm{C}_{\mathrm{V}}$, wT between the hourly mean wind speed $\mathrm{V}_{\mathrm{PED}}$ at pedestrian height and the hourly-mean wind speed $V_{R E F}$ at some reference height $Z_{R E F}$. In a perfect wind tunnel simulation $\mathrm{C}_{\mathrm{V}, \mathrm{WT}}$ is the same in the wind tunnel as the value $\mathrm{C}_{\mathrm{V}, \mathrm{IIS}}$ in situ. We assume that $\mathrm{C}_{\mathrm{V} \text {,WT }}$ has no systematic errors, but only a random error with standard deviation $\delta \mathrm{C}_{\mathrm{V}}$. So:

$\mathrm{C}_{\mathrm{V}, \mathrm{WT}}=\frac{\mathrm{V}_{\mathrm{PED}, \mathrm{WT}}}{\mathrm{V}_{\mathrm{REF}, \mathrm{WT}}}, \mathrm{C}_{\mathrm{V}, \mathrm{ISS}}=\frac{\mathrm{V}_{\mathrm{PED}, \mathrm{IS} S}}{\mathrm{~V}_{\mathrm{REF}, \mathrm{I} . \mathrm{S}}} \quad \mathrm{C}_{\mathrm{V}, \mathrm{WT}}=\mathrm{C}_{\mathrm{V}, \mathrm{IS} . \mathrm{S}} \pm \delta \mathrm{C}_{\mathrm{V}}$,

$V_{\text {REF,IS }}$ is discussed in section 4. It is defined as an in situ wind speed at a height $\mathrm{Z}_{\mathrm{REF}}$. The flow is assumed stationary and homogeneous. The flow corresponds

\footnotetext{
' German-Dutch Wind Tunnels (DNW), P.O. Box 175, 8300 AD Emmeloord, the Netherlands

${ }^{2}$ Eindhoven University of Technology, P.O. Box 513, 5600 MB Eindhoven, the Netherlands
} 
with a $z_{0}$-value that is representative for the oncoming flow at the investigated building site as function of wind direction.

In literature an effective wind speed $V_{\mathrm{EFF}}$ is defined, in which the effects of wind gusts on wind discomfort and danger are accounted for. The definition of an effective wind speed $V_{\mathrm{EFF}}$ in non-dimensional form is

$\mathrm{C}_{\mathrm{V}, \mathrm{EFF}}=\mathrm{C}_{\mathrm{V}} \cdot\left(1+\mathrm{K} \cdot \mathrm{I}_{\mathrm{U}}\right)$

$\mathrm{I}_{\mathrm{U}}$ is the longitudinal turbulence intensity and $\mathrm{K}$ has a value varying in literature between 0 to 3.5. With a typical value of $\mathrm{I}_{U}=0.20$ (i.e. $20 \%$ ), the difference between applying $\mathrm{K}=0$ and $\mathrm{K}=3.5$ results in a $70 \%$ difference in the $\mathrm{C}_{\mathrm{V} \text {,EFF }}$ value; this affects of course greatly the further results of the assessment. Wind tunnel test data may incorporate turbulence characteristics directly (the rmsvalue of the time signal of the wind speed sensor is measured) or indirectly (the time-mean value of the sensor output will be higher as a result of turbulence). This means that a proper choice of $\mathrm{K}$ should depend on the applied sensor in the wind tunnel. The heated thermistors as used in the Netherlands are expected to respond mainly on the time-mean wind speed and a high $\mathrm{K}$-value should then be used to define $\mathrm{V}_{\mathrm{EFF}}$. The matter of an effective wind speed coefficient and the corresponding error due to turbulence is further left out of discussion here.

To calculate the in situ wind speed at pedestrian height from a $\mathrm{C}_{\mathrm{V} \text {,WT }}$-value, we have to calculate $V_{\text {REF,IS }}$ from the hourly mean wind speed $V_{\text {METEO }}$ at $10 \mathrm{~m}$ height at a nearby meteorological station. Assuming a ratio $\mathrm{T}$ with a standard error $\delta \mathrm{T}$, we may write:

$\frac{V_{\text {REF,I.S. }}}{V_{\text {METEO }}}=T \pm \delta T$ and $V_{\text {PED,I.S }}=\left(C_{V, W T} \pm \delta C_{V}\right) \cdot(T \pm \delta T) \cdot V_{M E T E O}$

if $\mathrm{C}_{\mathrm{V}, \mathrm{IS}}=\mathrm{C}_{\mathrm{V}, \mathrm{WT}} \pm \delta \mathrm{C}_{\mathrm{V}}$

The standard error $\delta \mathrm{C}_{\mathrm{V}}$ will be discussed in section $3, \delta \mathrm{T}$ in section 4 and the effect on the accuracy of the calculated wind speeds at pedestrian height in section 5 . In section 6 the consequences for the assessment of the wind climate will be discussed.

\section{ACCURACY OF THE WIND SPEED COEFFICIENT}

The standard error $\delta \mathrm{C}_{\mathrm{V}}$ in equations 1 and 3 is caused by technical and simulation errors. These errors may originate from e.g.:

- Wind tunnel characteristics (short and long term change of the flow with time, drift of sensor accuracy and sensor sensitivity); 
- Extent of details in the model and in the surrounding area;

- Response of sensors to highly turbulent flow conditions (wind speed variations and flow angle variations);

- Differences between the simulated atmospheric boundary layer (ABL) and the in situ $\mathrm{ABL}$ (in wind tunnel experiments the $\mathrm{ABL}$ profile does not, or seldom change with wind direction);

- Choice of the reference height.

In 1992 a round-robin test was performed between three independently operating wind tunnels in the Netherlands.

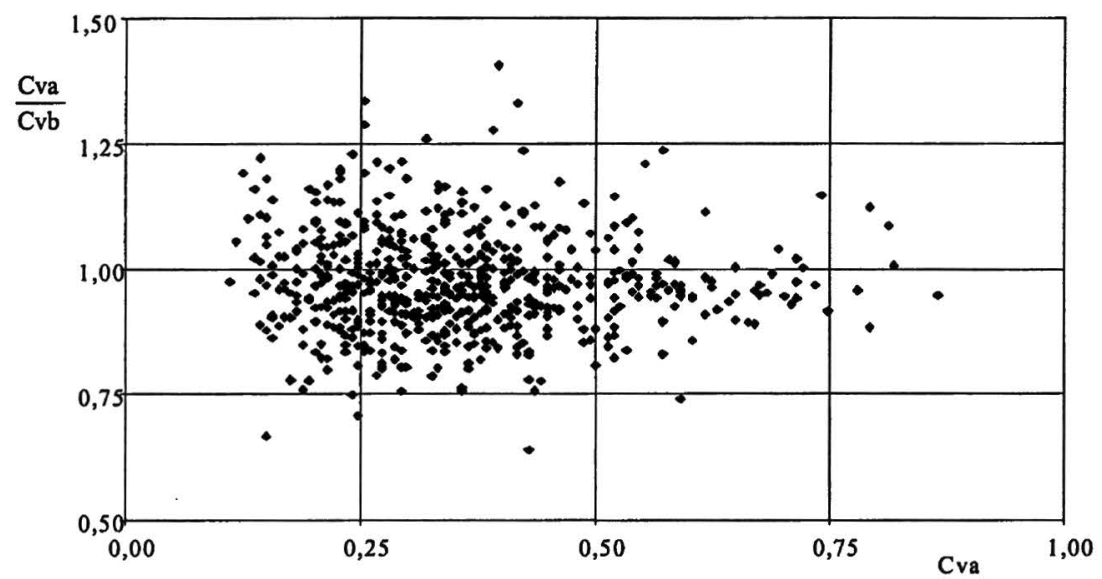

Figure 1. Result of the round robin test. The ratio of $\mathrm{C}_{\mathrm{V}, \mathrm{WT}}$ determined with wind tunnel $\mathrm{A}$ to $\mathrm{C}_{\mathrm{V} \text {,WT }}$ determined with wind tunnel $\mathrm{B}$, for 52 positions as function of $\mathrm{C}_{\mathrm{V}, \mathrm{WT}}$ determined with wind tunnel $\mathrm{A}$.

An imaginary built environment was defined and modelled on scale 1:250. The same physical model was used by all three parties and tested under a simulated $\mathrm{ABL}$, as used by the separate wind tunnels for $\mathrm{z}_{\mathrm{o}}=0.03 \mathrm{~m}$. At 52 positions $\mathrm{C}_{\mathrm{V}, \mathrm{WT}}$ was calculated for 24 wind directions (step size $15^{\circ}$ ). The results of one wind tunnel had a systematic deviation; this will not be discussed further, as a systematic error might be solved in principle. For the present discussion the random errors are of interest. Comparing any two wind tunnels resulted in a similar conclusion. Figure 1 gives the result for wind tunnels " $A$ " and " $B$ ". The ratios between the $\mathrm{C}_{\mathrm{V}}$-values at similar wind direction from the two wind tunnels are plotted along the vertical axis and the $\mathrm{C}_{\mathrm{V}}$-values for wind tunnel "A" along the horizontal. The results show a bandwidth of approximately 50 per cent. A standard deviation of $12 \%$ was calculated. 
The round-robin test only covers a part from the above-summarised possible technical and simulation errors. The remaining errors may have considerable effects, especially a mismatch in the velocity profile. Although generally, the building location is characterised by different upstream surface roughness at varying wind directions, routine wind simulations use one surface roughness for all wind directions. A description of the upstream roughness will easily be one class off in the roughness classification (Wieringa 1992), with noticeable effects on wind speed and turbulence characteristics. If for example $z_{0}=1 \mathrm{~m}$ or $0.5 \mathrm{~m}$ en if the displacement length $\mathrm{d}=10 \mathrm{~m}$, the longitudinal turbulence intensity $\mathrm{I}_{U}$ at height $\mathrm{z}=50 \mathrm{~m}$ is either $27 \%$ or $22 \%$. The integral turbulence length scale $\mathrm{L}_{X}$ is inversely proportional to $\left(\mathrm{I}_{u}\right)^{2}$. If the wind speed $\mathrm{V}_{\mathrm{REF}}$ is kept constant, $\mathrm{L}_{\mathrm{X}}$ varies then a factor 1.5. Moreover, the integral turbulence length scale varies a factor 4 with stability (Tieleman 2001). The effect of a miss-modelled integral turbulence length scale on separation in the flow might be considerably. We have no information on the magnitude of this error with regard to pedestrian level wind tests.

It is suggested (ASCE 1999) that the effect of stability may be compensated by climatologically averaging. For the effect of a non-realistic roughness length this may not be expected. Stability will also significantly affect the wind characteristics.

The present authors estimate that apart form the round robin test the errors discussed will cause an extra standard deviation in $\mathrm{C}_{\mathrm{V}}$ of at least the same order of magnitude, i.e. another $12 \%$. The total standard deviation is then at least $15 \%$, i.e. $\delta \mathrm{C}_{\mathrm{V}} / \mathrm{C}_{\mathrm{V}}=0.15$.

\section{ACCURACY OF THE REFERENCE WIND}

The ratio $\mathrm{T}$ in equation 3 represents the transfer from the documented wind speed at a nearby meteorological station to the wind speed at reference height. An estimate of $T$ based on values for the surface roughness at varying wind direction and an internal boundary layer growth model in a neutral atmosphere. This estimate incorporates errors.

De Wit et al (2001) analysed wind measurements over Eindhoven. They found that the error in the calculated T-value had a standard deviation of about $9 \%$. They also found a random wind speed variation at a reference height of $42 \mathrm{~m}$ with a standard deviation of $0.7 \mathrm{~m} / \mathrm{s}$. At wind speeds relevant in wind comfort studies (threshold wind speeds of $5 \mathrm{~m} / \mathrm{s}$ ) this is almost $15 \%$. An additional error in the source data of $\mathrm{V}_{\text {METEO }}$ of say $10 \%$ will also affect the $\mathrm{V}_{\mathrm{REF}, \mathrm{IS}}$ for another $10 \%$. For the time being, the present authors estimate from above considerations the standard error in $\mathrm{T}$ as $15 \%$, i.e. $\delta \mathrm{T} / \mathrm{T}=0.15$. 


\section{ACCURACY OF THE PEDESTRIAN LEVEL WIND SPEED}

The estimates of $\delta \mathrm{C}_{\mathrm{V}}=15 \%$ and $\delta \mathrm{T}=15 \%$ mean that according to equation 3 the in situ pedestrian level wind speed $\mathrm{V}_{\mathrm{PED}, \mathrm{IS}}$ can be estimated within a standard deviation of about $20 \%$.

Isyumov (1995) compared in a study at the campus of the University of Western Ontario the mean wind speed coefficients measured in situ $\mathrm{C}_{\mathrm{V}, \mathrm{I.S}}$ with wind tunnel coefficients $C_{V \text {,WT. }}$. The $V_{\text {REF,IS }}$ was estimated from $V_{\text {METEO }}$ and a reference anemometer at another location of the campus. The present authors estimate that these data show a range for $\mathrm{C}_{\mathrm{V}, \mathrm{IS}} / \mathrm{C}_{\mathrm{V}, \mathrm{WT}}$ of 0.4 to 1.6 , with at $\mathrm{C}_{\mathrm{V}, \mathrm{wT}}=0.5$ a standard error of about $20 \%$. The small amount of data is in line with the present error estimate.

Visser and Cleijne (1994) measured $V_{\text {REF,I.S }}$ for a low-rise location in wooded countryside in the Netherlands and estimated the roughness lengths $z_{0}$ of the foreland. The authors studied four locations. At an optimal choice of $\mathrm{z}_{\mathrm{o}}$ they found values of $\mathrm{C}_{\mathrm{V} \text {,I.S }} / \mathrm{C}_{\mathrm{V} \text {,WT }}$ of 0.8 to 1.2 in a winter half-year and of 0.6 to 1.0 in a summer half-year. For all four locations together they found $\mathrm{C}_{\mathrm{V}, \mathrm{ILS}}=0.06+0.93 \mathrm{C}_{\mathrm{V}, \mathrm{WT}}$ (correlation coefficient $\mathrm{r}=0.87$ ) in winter and $\mathrm{C}_{\mathrm{V}, \mathrm{I} . \mathrm{S}}=0.12+0.70 \mathrm{C}_{\mathrm{V}, \mathrm{WT}}(\mathrm{r}=0.78)$ in summer. These data are also in line with the present error discussion.

Williams and Wardlaw (1992) studied the wind regime in the city of Ottawa. The wind speed $V_{\text {LOC }}$ at a $213-\mathrm{m}$ high measuring point was found to be 1.226 times the $\mathrm{V}_{\text {METEO }}$ value. They required 1250 hours of data to get this ratio within a $10 \%$ of the mean value and 2935 hours for a better than $0.5 \%$. This information indicates that the standard deviation of this ratio is surprisingly great. The correlation coefficient between $\mathrm{C}_{\mathrm{V}, \mathrm{IS}}$ (with $\mathrm{V}_{\mathrm{REF}}$ being the gradient wind) and $\mathrm{C}_{\mathrm{V}, \mathrm{wr}}$ was only 0.7 , indicating that the wind tunnel simulation could not explain half of the variance. However, the ratios of the pedestrian level winds and the wind speeds at the closest tower as determined in situ and in the wind tunnel correlated very well. The study of Williams and Wardlaw illustrates very well the difficulty in the calculation of $\mathrm{T}$ in equation 3 , even if the wind tunnel simulation is completed with in situ measurements.

Murakami et al (1979) compared $C_{V, I S}$ (with $V_{R E F}$ at $120 \mathrm{~m}$ height) and $C_{V, W T}$. From their scatter diagram the present authors conclude to a standard error of $40 \%$ at $\mathrm{C}_{\mathrm{V}, \mathrm{IS}}=0.2$ to $10 \%$ at $\mathrm{C}_{\mathrm{V}, \mathrm{ILS}}=0.8$.

\section{CODIFICATION OF WIND COMFORT}

More than 25 years ago it was already recognised that thermal comfort and the cooling effects from wind should be considered in the assessment of wind discomfort. Recent work from Sasaki et al. (2000) and Stathopoulos et al. (1999) renewed this attention to thermal effects. In this paper the assessment of wind discomfort is restricted to the probability $P_{i}$ for a location $i$ that a local wind speed $V_{\text {PED,I.S }}$ exceeds a certain threshold value $V_{\text {THR }}$. 
$P_{i}=\Sigma_{n} P_{i}\left(V_{P E D, I S}>V_{T H R}\right)=\Sigma_{n} P_{i}\left\{\left(C_{V, W T} \pm \delta C_{V}\right) \cdot(T \pm \delta T) \cdot V_{M E T E O}>V_{T H R}\right\}=$ $=P_{A V G, i} \pm S D_{i}$

$\mathrm{n}$ being the number of wind direction classes in the wind tunnel simulation. Because of the climate of the region and the geometry of the built environment $\mathrm{P}\left(\mathrm{U}_{\mathrm{REF}}>\mathrm{X}\right)$ and $\mathrm{C}_{\mathrm{V}}$ are both a function of wind direction. Therefore, a generalised answer on the value of $\mathrm{SD}_{i}$ is impossible. We performed a test with a wind tunnel generated set of $\mathrm{C}_{\mathrm{V}, \mathrm{WT}}$ for 76 measuring points in a model of a $19^{\text {th }}$ century quarter with additional high rise. For each measuring point $P_{i}$ has been calculated with wind climate data of Amsterdam airport. To demonstrate the effect of $\delta \mathrm{C}_{\mathrm{V}}=15 \%$ and $\delta \mathrm{T}=15 \%$ we chose randomly 10 numbers from a normal distribution with a standard deviation of $20 \%$. From the 11 numbers for every measuring point a mean $\mathrm{P}_{\mathrm{AVG}}$ and a standard deviation $\mathrm{SD}_{\mathrm{i}}$ has been calculated. Figure 2 and 3 present $P_{A V G, i}$ and corresponding $S_{i}$ values for $V_{T H R}=5$ and 15 $\mathrm{m} / \mathrm{s}$ respectively.
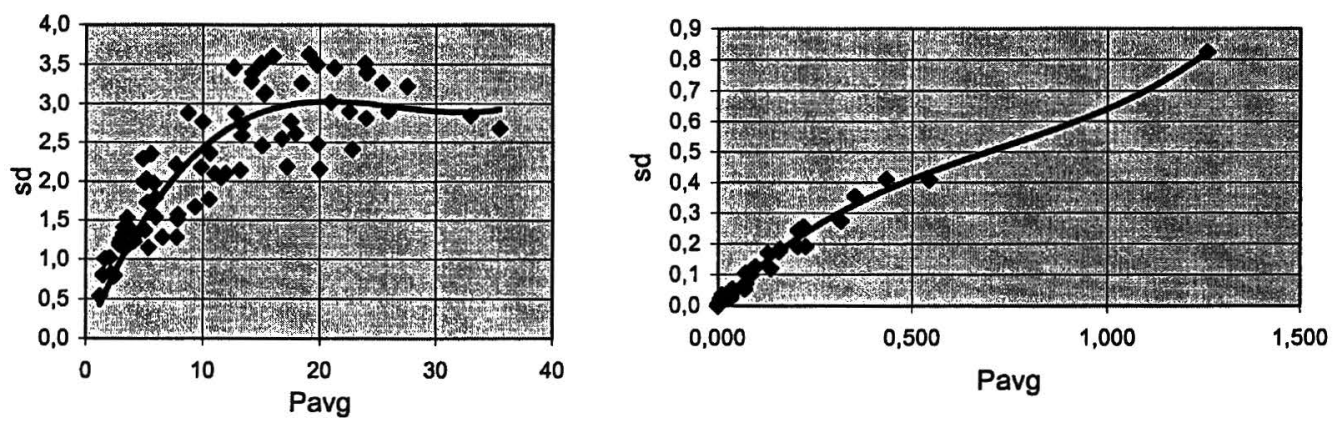

Figure 2 and 3. $\mathrm{P}_{\mathrm{AVG}, \mathrm{i}}$ and $\mathrm{SD}_{\mathrm{i}}$ values in percent for 76 measuring points. Wind climate of Amsterdam Airport. $\delta \mathrm{C}_{\mathrm{V}}=\delta \mathrm{T}=15 \%$. Figure 2: $\mathrm{Vthr}=5 \mathrm{~m} / \mathrm{s}$; Figure $3: \mathrm{Vthr}=15 \mathrm{~m} / \mathrm{s}$.

To implement a wind comfort criterion in building practice, which consists of a value for $V_{T H R}$ and a maximum probability $P_{\text {MAX }}$ for $P_{i}$, we have to choose the probability that

$\mathrm{P}_{\mathrm{i}}-\mathrm{P}_{\mathrm{MAX}}>0$

This means that we have to choose the level of certainty, which we can claim for our evaluation of the quality of the wind climate in the building project. Let us assume that it will be required that $\mathrm{P}_{\mathrm{i}}-\mathrm{P}_{\mathrm{MAX}}$ will only be positive with a probability less than $3.6 \%$. This means that if we apply a normal distribution

$\mathrm{P}_{\mathrm{AVG}, \mathrm{i}}+1.8 \mathrm{SD}_{\mathrm{i}}<\mathrm{P}_{\mathrm{MAX}}$ 
If we choose $\mathrm{SD}_{\mathrm{i}}=3 \%$ for comfort assessment (figure 2) and require that the local velocity is greater than $5 \mathrm{~m} / \mathrm{s}$ in less than $20 \%$ of the time, the above discussion implies that a wind tunnel simulation should demonstrate that $\mathrm{P}_{\mathrm{AVG}, \mathrm{i}}<15 \%$ to meet this requirement.

Moreover, if we adapt the safety requirement that $V_{P E D}$ only exceeds $15 \mathrm{~m} / \mathrm{s}$ in $0.5 \%$ of the time and see from figure 3 that now $\mathrm{SD}_{i}$ is $0.4 \%$ we find that a wind tunnel simulation should demonstrate that $\mathrm{P}_{\mathrm{AVG}, \mathrm{i}}<0.5-1.8 \mathrm{x} 0.4$ or $\mathrm{P}_{\mathrm{AVG}, \mathrm{i}}=0$.

\section{CONCLUSION}

A conservative estimate of the standard error of the pedestrian level wind speed in the built environment is $20 \%$. Consequently, the standard error in the probability that the local wind speeds exceed a threshold value is given by figures 2 and 3.

A complete discussion of the accuracy of wind tunnel simulation of local wind speed is not possible. In particular the technical and aerodynamical errors involved in the simulation are not sufficiently documented. Also the uncertainty in the threshold values for wind comfort and safety as well as the determination of the local turbulent intensity are neglected in the present discussion. A tentative conclusion is that an evaluation of a building plan with a wind tunnel simulation is feasible, but the errors involved should be taken into account while formulating the required probability that local wind speed exceeds a threshold value.

\section{REFERENCES}

ASCE.1999. Wind tunnel studies of buildings and structures, ASCE Manuals and Reports on Engineering Practice No. 67

Isyumov, N. 1995. Full-scale studies of pedestrian winds: comparisons with wind tunnel and evaluation of human comfort, Restructuring: America and beyond; Proc. Of Structures Congress XIII, pp. 104-107

Murakami, S.; K. Uehara and K. Deguchi. 1979. Wind effects on pedestrians: new criteria based on outdoor observations of over 2000 persons, Wind Engineering, Cermak J.E. editor, pp. 277-278

Sasaki, R; Y. Yamada; Y. Uematsu and H. Saeki. 2000. Comfort environment assessment based on bodily sensation in open air: relationship between comfort sensation and meteorological factors, JWEIA 87, pp. 93-110

Stathopoulos,Th; H.Wu and J. Zacharias.1999. Field survey on outdoor human comfort in urban climate, Wind Engineering into the $21^{\text {st }}$ Century, Larose et.al.,Balkema, 1999 
Tieleman, H. 2001. Wind loads on low-rise structures: wind tunnel experiments. Proceedings 3EACWE,Vol A

Visser, G.Th; J.W. Cleijne, Wind comfort predictions by wind tunnel tests: comparison with full-scale data; JWEIA, 52 (1994) pp. 385-402

Wieringa, J.1992. Updating the Davenport roughness classification. Journal of Wind Engineering and Industrial Aerodynamics, pp. 41-44, pp. 357-368

Williams, C.D. and R.L. Wardlaw. 1992. Determination of the pedestrian wind environment in the city of Ottawa using wind tunnel and field measurements, J. of Wind Engineering and Industrial Aerodynamics, pp. 41-44, pp. 255-266

Wit, M.H. de; J.A. Wisse. 2001.Wind data analysis in the center of Eindhoven, Proceedings 3EACWE, Eindhoven, 2001 